\title{
Relative growth and morphological sexual maturity of Chasmagnathus granulatus (Crustacea, Varunidae) from a mangrove area in southeastern Brazilian coast
}

\author{
Rafael Augusto Gregati \& Maria Lucia Negreiros-Fransozo
}

NEBECC (Grupo de Estudos em Biologia, Ecologia e Cultivo de Crustáceos), Departamento de Zoologia - Universidade Estadual Paulista, UNESP, 18618-000 Botucatu, SP, Brazil. (gregati@ibb.unesp.br; mlnf@ibb.unesp.br)

\begin{abstract}
The relative growth and morphological sexual maturity of Chasmagnathus granulatus Dana, 1851 are presented for the first time to a mangrove population. The crabs were obtained during low tide periods, in the mangrove of Jabaquara Beach, Paraty, Rio de Janeiro, Brazil. All crabs in intermolt stage were sexed and had their body parts measured as follows: body height (BH), carapace length $(\mathrm{CL})$ and width (CW), major cheliped propodus height (PH) and length (PL) for each sex, gonopod length (GL) and abdomen width (AW) for males and females, respectively. The relative growth was described using the allometric equation $y=a x^{b}$ and the size at onset sexual maturity was achieved using the software Mature I. The size of specimens ranged from $4.1 \mathrm{~mm}$ to $39.5 \mathrm{~mm} \mathrm{CW}$. The growth pattern was different between sexes in the cheliped relationships; the relationships BH vs. CW evidenced positive allometry for juveniles; PL vs. CW and $\mathrm{PH} v$ s. CW positive allometry for most crabs except juvenile females; AW vs. CW and GL vs. CW evidenced positive allometry for juveniles and isometry for adults. The relationships that best indicated the change from the juvenile to the adult phase were PH vs. CW for males and AW vs. CW for females. The size in which 50\% of males from this population are mature is at $19.7 \mathrm{~mm}$ of $\mathrm{CW}(\mathrm{F}=144.14$; $\mathrm{p}<0.05)$ and for females it is at $19.2 \mathrm{~mm}$ of $\mathrm{CW}(\mathrm{F}=166.54 ; \mathrm{p}<0.05)$. The sizes obtained in this mangrove population are larger than those from previous studies, that could be attributed to a species plasticity concerning the habitat structure.
\end{abstract}

KEYWORDS. Grapsoidea, semiterrestrial crabs, morphometric relationships, allometric growth.

RESUMO. Crescimento relativo e maturidade sexual morfológica de Chasmagnathus granulatus (Crustacea, Varunidae) de uma área de manguezal no sudeste do Brasil. O crescimento relativo e a maturidade sexual morfológica de Chasmagnathus granulatus Dana, 1851 são apresentados pela primeira vez para uma população de manguezal. Os caranguejos foram obtidos durante os períodos de maré baixa, no manguezal da praia do Jabaquara, Paraty, Rio de Janeiro, Brasil. Todos os caranguejos em estágio de intermuda foram classificados quanto ao sexo e as seguintes medidas lineares foram tomadas: altura do corpo (AC), altura do própodo do quelípodo maior (APQ), comprimento da carapaça (CC), comprimento do própodo do quelípodo maior (CPQ), largura da carapaça (LC), comprimento do gonopódio (CG) e largura do abdome (LA) para machos e fêmeas, respectivamente. O crescimento relativo foi descrito a partir da equação alométrica $y=a x^{b}$ e o programa Mature I utilizado para a estimativa do tamanho na maturidade. O tamanho dos espécimes variou de 4,1 $\mathrm{mm}$ a $39,5 \mathrm{~mm}$ de LC. O padrão de crescimento foi diferente entre os sexos nas relações com o quelípodo, as relações AC vs. LC evidenciaram alometria positiva para juvenis, CPQ vs. LC e APQ vs. LC alometria positiva para quase todos caranguejos exceto fêmeas jovens e LA vs. LC e CG vs. LC evidenciaram alometria positiva para jovens e isometria para adultos. As relações que melhor evidenciaram a mudança da fase juvenil para a adulta foram APQ vs. LC para machos e LA vs. LC para fêmeas. O tamanho no qual $50 \%$ dos machos da população encontram-se maduros foi estimado em 19,7 mm de LC ( $\mathrm{F}=144,14 ; \mathrm{p}<0,05)$ e para as fêmeas em 19,2 mm LC (F=166,54; $\mathrm{p}<0,05)$. Os tamanhos obtidos nesta população de manguezal são maiores do que aqueles obtidos em estudos anteriores, o que pode ser atribuído a plasticidade da espécie em relação a estrutura do habitat.

PALAVRAS-CHAVE. Grapsoidea, caranguejos semiterrestres, relações morfométricas, crescimento alométrico.

The estuarine crab Chasmagnathus granulatus Dana, 1851 has an important role in the intertidal areas, moving great amounts of sediment to catch food and for the maintenance of the burrows, influencing the quality, penetrability and transport of the substratum (Bотто \& IRIBARNe, 2000). Several authors have studied $C$. guanulatus concerning many biologic subjects up to date, including its relative growth and sexual maturity (RUFFINO et al., 1994; LÓPEZ et al., 1997; LÓPEZ-GRECO \& RODRÍGUEZ, 1999; LuPPI et al., 2004), but none has investigated a mangrove population.

Information about growth frequently is used to evidence changes in the development stages of the animals, for example, size in the sexual maturity (VANINI \& GUERARDI, 1988). The size in which a certain species reaches its sexual maturity represents an important parameter for the understanding of the brachyuran's life cycle (HARTNOLL \& GoULD, 1988).

According to HARTNOLL (1982), the relative growth is defined by means of the growth of different body parts in relation to a body dimension that expresses the animal size as a whole. The level of allometry and the growth pattern can suggest the size in which the animal attains the morphological sexual maturity (GoNZÁLEZ-GURRIARÁN \& FREIRE, 1994)

The objective of this paper was to determine the relative growth and the size at onset of the morphological sexual maturity of a unique population of $C$. granulatus from a tropical mangrove area.

\section{MATERIAL AND METHODS}

The samplings were carried out monthly, from April 2003 to March 2004, in the mangrove associated to Jabaquara beach, along the Jabaquara River, Paraty, south state of Rio de Janeiro, Brazil (2313'04'S and $\left.44^{\circ} 42^{\prime} 47^{\prime \prime} \mathrm{W}\right)$.

The crabs were captured manually in low tide 
period, inside their burrows along the principal river, by two collectors over a period of 45 minutes. The crabs were bagged, labeled and stored frozen until the morphometric analysis in the laboratory.

The sex of each crab was recorded and the following body dimensions were measured with a digital caliper $(0.01 \mathrm{~mm})$ : body height $(\mathrm{BH})$, carapace length (CL) and width $(\mathrm{CW})$, major cheliped propodus height $(\mathrm{PH})$ and length (PL), abdomen width for females (AW) and gonopod length (GL) for males (Fig. 1). Only intermolt crabs were used in this analysis.

The median sizes of males and females are compared by Mann-Whitney test at 5\% significance (ZAR, 1996).

The morphometric data were plotted in dispersion graphics, the relative growth was described from the adjustment of the points to the alometric equation $y=a x^{b}$ and linearized $(\log y=\log a+b \log x)$ (HUXLEY, 1950). The $\mathrm{CW}$ was used as independent variable (" $x$ ") and related with the other corporal dimensions (" $y$ "). The " $b$ " of the equation express the allometric coefficient and its value was submitted to $t$ of Student test (Ho: $\mathrm{b}=1 ; \alpha=5 \%$ ). The slopes and the intercepts were analyzed by covariance analysis (ANCOVA, $\alpha=5 \%$ ) between sexes and between development phases (ZAR, 1996).

The Mature I software (SOMERTon, 1980) was adopted to estimate the size at onset of sexual maturity for crabs, based on the regression analysis of relative growth. In this case, two values (juvenile bound and adult bound) are chosen such that the " $x$ " axis is divided into three regions: the leftmost region (juveniles), the rightmost region (adults) and middle region (unknown mixture of juveniles and adults. Preliminary estimates of the two phase lines are made by fitting straight lines, using linear regression, to the known juvenile and adult data. The lines are extrapolated into the middle region and the difference in " $y$ " direction between every data point and each of the two lines is calculated. According to SOMERTON (1980), the test statistic has an $F$ distribution.

\section{RESULTS}

A total of 599 crabs ( 351 males and 248 females), with a size range of $4.1 \mathrm{~mm}$ to $39.5 \mathrm{~mm}$ of $\mathrm{CW}(24.4 \pm 7.5)$ were used for the analyses of relative growth and morphological sexual maturity.

The males attained sizes greater than females (Mann-Whitney test, $\mathrm{p}<0.05$ ) and the growth curves of the juvenile and adult phases differed in all the regressions (ANCOVA, $\mathrm{p}<0.05$ ). The growth pattern was different between sexes in the cheliped relationships (PL vs. $\mathrm{CW}$ and $\mathrm{PH} v s . \mathrm{CW})$ and in the relationship CL vs. CW for adults (ANCOVA, $\mathrm{p}<0.05$ ), while the relationship CL $v s$. $\mathrm{CW}$ for juveniles and $\mathrm{BH} v s . \mathrm{CW}$ for juveniles and adults also presented the same growth pattern for both sexes (ANCOVA, $p>0.05$ ).

The relationships studied in the relative growth and allometric levels of $C$. granulatus are presented in Table I. The analysis of the relationship BH vs. CW evidenced positive allometry for juvenile males and juvenile females, while the adults of both sexes presented isometry. For the relationship CL vs. CW both sexes presented isometry, except adult females that presented negative allometry.

The relationships PL vs. CW and PH vs. CW indicated a positive allometry for most crabs except juvenile females, which presented isometry in the relation
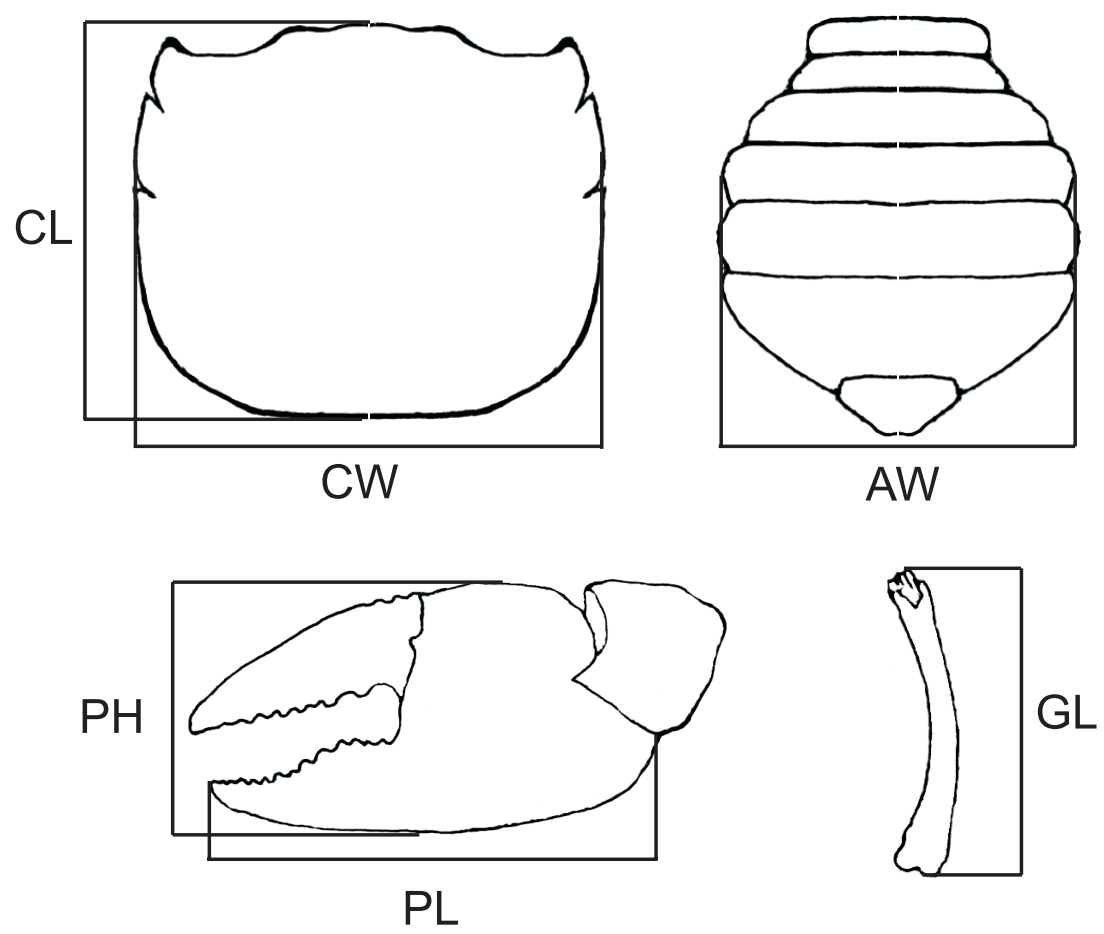

Fig. 1. Body dimensions for Chasmagnathus granulatus Dana, 1851 (not in scale): AW, abdomen width of the females; BH, body height; CL, carapace length; CW, carapace width; GL, gonopod length; PH, major cheliped propodus height and PL, major cheliped propodus length. 
PL vs. CW. The relationship AW vs. CW (for females) and GL vs. CW (for males) evidenced positive allometry for juveniles and isometry for adults. The relationships that evidenced the maturity and showed a change in the growth pattern were $\mathrm{PH} v s$. $\mathrm{CW}$ for males and $\mathrm{AW} v s$. $\mathrm{CW}$ for females (Fig. 2).

The size of morphological sexual maturity of $C$. granulatus in $50 \%$ of the males in the studied population was $19.7 \mathrm{~mm}$ of CW, being $14.7 \mathrm{~mm}$ of $\mathrm{CW}$ the smallest mature male and $25.0 \mathrm{~mm}$ of $\mathrm{CW}$ the largest immature male $(\mathrm{F}=80.64 ; \mathrm{p}<0.05)$ (Figs. 2, 3). For females, the size at which $50 \%$ were mature was $19.2 \mathrm{~mm}$ of $\mathrm{CW}$, being 17.5 $\mathrm{mm}$ of $\mathrm{CW}$ the smallest mature female and $22.6 \mathrm{~mm}$ of $\mathrm{CW}$ the largest immature female $(\mathrm{F}=166.54 ; \mathrm{p}<0.05)$ (Figs. 2, 3).

Table I. Results of the analysis of regression for the morphometric data of Chasmagnathus granulatus Dana, 1851 from the mangrove associated to Jabaquara beach, in Paraty, south state of Rio de Janeiro, Brazil, with the carapace width (CW) used as independent variable (N, specimens number; JM, juvenile male; AM, adult male; JF, juvenile female; AF, adult female; "0", isometry; "_", negative allometry; "+", positive allometry; *, significant at $5 \% ; r^{2}$, determination coefficient; $t$, statistic values; AW, abdomen width of the females, BH, body height, CL, carapace length, CW, carapace width, GL, gonopod length, PH, major cheliped propodus height and PL, major cheliped propodus length).

\begin{tabular}{|c|c|c|c|c|c|c|c|c|}
\hline \multirow[t]{2}{*}{ Relation } & \multirow[t]{2}{*}{ Category } & \multirow[t]{2}{*}{$\mathrm{N}$} & \multirow{2}{*}{$\begin{array}{l}\text { Power function } \\
\qquad\left(y=a x^{b}\right)\end{array}$} & \multirow[t]{2}{*}{$r^{2}$} & \multirow[t]{2}{*}{$\mathrm{t}(\mathrm{b}=1)$} & \multirow{2}{*}{$\begin{array}{l}\text { Allometric } \\
\text { index }\end{array}$} & \multicolumn{2}{|c|}{ Results of Mature I } \\
\hline & & & & & & & $\mathrm{F}$ value & Cut point \\
\hline \multirow[t]{4}{*}{$\mathrm{BH} v s . \mathrm{CW}$} & $\mathrm{JM}$ & 64 & $\mathrm{BH}=0.408 \mathrm{CW}^{1.102}$ & 0.979 & $5.10 *$ & + & & \\
\hline & $\mathrm{AM}$ & 275 & $\mathrm{BH}=0.666 \mathrm{CW}^{0.933}$ & 0.818 & 1.22 & 0 & & \\
\hline & $\mathrm{JF}$ & 72 & $\mathrm{BH}=0.431 \mathrm{CW}^{1.078}$ & 0.991 & $7.10^{*}$ & + & & \\
\hline & $\mathrm{AF}$ & 139 & $\mathrm{BH}=0.493 \mathrm{CW}^{1.031}$ & 0.959 & 1.72 & 0 & & \\
\hline \multirow[t]{4}{*}{$\mathrm{CL} v s . \mathrm{CW}$} & $\mathrm{JM}$ & 69 & $\mathrm{CL}=0.803 \mathrm{CW}^{1.015}$ & 0.989 & 1.25 & 0 & & \\
\hline & $\mathrm{AM}$ & 282 & $\mathrm{CL}=1.035 \mathrm{CW}^{0.927}$ & 0.839 & 1.46 & 0 & & \\
\hline & $\mathrm{JF}$ & 73 & $\mathrm{CL}=0.790 \mathrm{CW}^{1.021}$ & 0.990 & 1.90 & 0 & & \\
\hline & $\mathrm{AF}$ & 175 & $\mathrm{CL}=0.984 \mathrm{CW}^{0.952}$ & 0.975 & $4.36 *$ & - & & \\
\hline \multirow[t]{4}{*}{$\mathrm{PL}$ vs. $\mathrm{CW}$} & $\mathrm{JM}$ & 63 & $\mathrm{PL}=0.301 \mathrm{CW}^{1.255}$ & 0.976 & $10.62 *$ & + & & \\
\hline & $\mathrm{AM}$ & 257 & $\mathrm{PL}=0.127 \mathrm{CW}^{1.544}$ & 0.797 & $5.60 *$ & + & & \\
\hline & JF & 68 & $\mathrm{PL}=0.483 \mathrm{CW}^{1.026}$ & 0.971 & 1.238 & 0 & & \\
\hline & $\mathrm{AF}$ & 161 & $\mathrm{PL}=0.401 \mathrm{CW}^{1.089}$ & 0.950 & $4.684^{*}$ & + & & \\
\hline \multirow[t]{4}{*}{$\mathrm{PH}$ vs. $\mathrm{CW}$} & $\mathrm{JM}$ & 63 & $\mathrm{PH}=0.090 \mathrm{CW}^{1.451}$ & 0.945 & $10.25 *$ & + & 80.64 & $19.7 \mathrm{~mm}$ \\
\hline & $\mathrm{AM}$ & 218 & $\mathrm{PH}=0.042 \mathrm{CW}^{1.721}$ & 0.764 & $6.00 *$ & + & & \\
\hline & JF & 72 & $\mathrm{PH}=0.157 \mathrm{CW}^{1.158}$ & 0.970 & $6.87^{*}$ & + & & \\
\hline & $\mathrm{AF}$ & 152 & $\mathrm{PH}=0.134 \mathrm{CW}^{1.217}$ & 0.965 & $12.05 *$ & + & & \\
\hline \multirow[t]{2}{*}{$\mathrm{AW} v s . \mathrm{CW}$} & JF & 55 & $\mathrm{AW}=0.121 \mathrm{CW}^{1.425}$ & 0.947 & $9.44 *$ & + & 166.54 & $19.2 \mathrm{~mm}$ \\
\hline & $\mathrm{AF}$ & 138 & $\mathrm{AW}=0.231 \mathrm{CW}^{1.281}$ & 0.843 & 0.33 & 0 & & \\
\hline \multirow[t]{2}{*}{ GL vs. CW } & $\mathrm{JM}$ & 64 & $\mathrm{GL}=0.258 \mathrm{CW}^{1.107}$ & 0.939 & $3.05 *$ & + & & \\
\hline & $\mathrm{AM}$ & 238 & $\mathrm{GL}=0.272 \mathrm{CW}^{1.082}$ & 0.757 & 1.08 & 0 & & \\
\hline
\end{tabular}
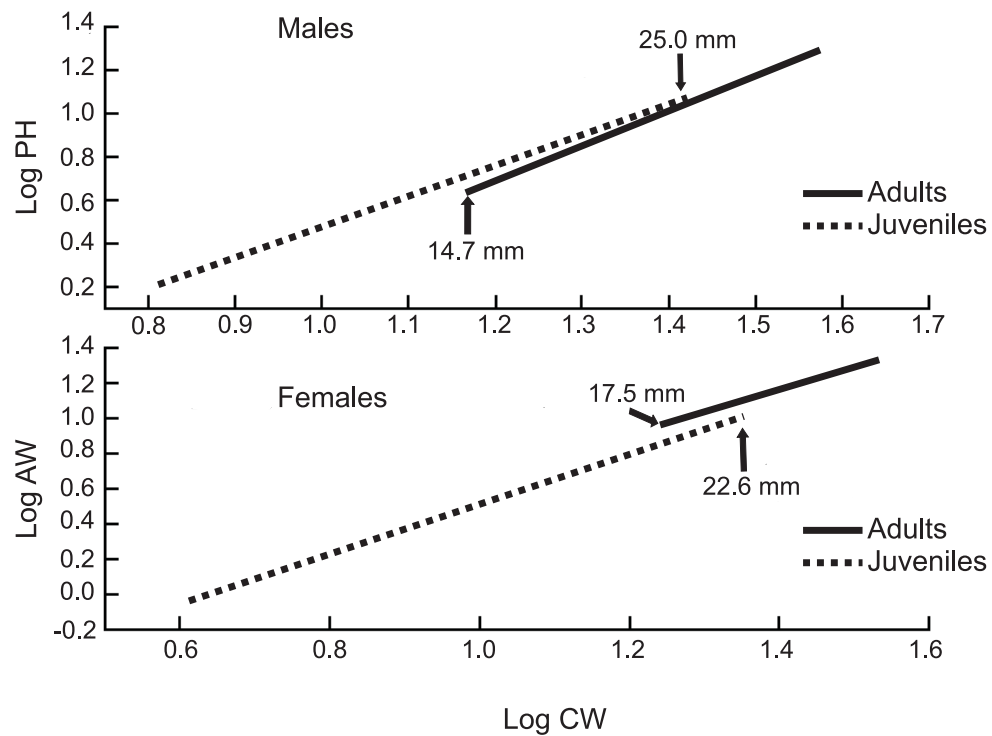

Fig. 2. Linear regression of relationships $\mathrm{PH}$ vs. CW for males and AW vs. CW for females of Chasmagnathus granulatus Dana, 1851 from the mangrove associated to Jabaquara beach, Paraty, south state of Rio de Janeiro, Brazil, indicating the different straight lines for juveniles and adults, based in the Mature I software results. 


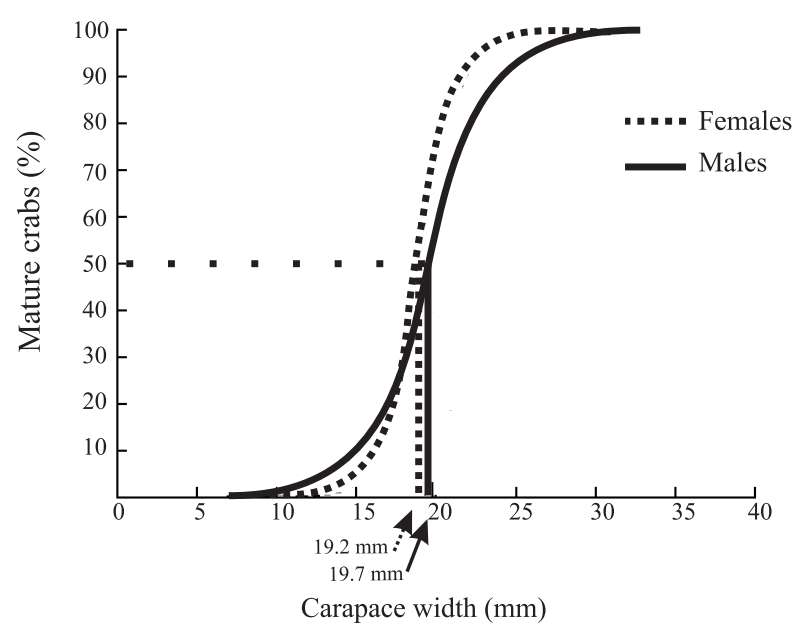

Fig. 3. Adjustment of the logistic equation indicating the carapace width of Chasmagnathus granulatus Dana, 1851 from the mangrove associated to Jabaquara beach, Paraty, south state of Rio de Janeiro, Brazil, where $50 \%$ of the crabs are morphologically mature.

\section{DISCUSSION}

The availability and the quality of the food, besides an adequate substratum in the environment are the main factors that influence the growth and size of the crabs (Genoni, 1985; Colpo \& Negreiros-Fransozo, 2002). The size variations are common and it can be due to the phenotypic plasticity of the organisms or influenced by environmental factors (as photoperiod, temperature and rainfall) that also affect the food availability (CAMPBELL $\&$ EAGLES, 1983). Such factors can explain the larger size of $C$. granulatus specimens from Paraty, when compared with the majority of the other population of the same species (Tab. II). CondE \& DíAz (1989) found differences in the size among Aratus pisonii (H. Milne Edwards, 1837) populations and attributed such difference to the food availability in the environment. Thus, in the case of $C$. granulatus, probably the species finds more alimentary resources in the mangrove ecosystem than in other estuarine environments, as the salt marshes.
Frequently among the crustaceans, females present a slower growth after the sexual maturity, probably in function of the energy resource aiming for the egg production (HaRTNOLl, 1982; Díaz \& CONDE, 1989; HAEFNER \& SPAARGAREN, 1993). It is common to find males reaching larger sizes than females, as in this study. According to WARNER (1967) and DíAz \& CONDE (1989), such fact could be a consequence of the reproductive period that demands more energy resources for the females. Other factors as different mortality rates between sexes (Wolf et al., 1975), migration (Montague, 1980), the greater facility of one sex to support the ambient adversities, the spatial and temporal disequilibrium between sexes in the use of the environmental resources and behavior (Giesel, 1972) can also influence the difference of size between sexes of the same species.

The size in which males of $C$. granulatus reached the morphological sexual maturity was higher than the value found for females, similar to the pattern proposed by SHINe (1988) for brachyurans. According to such author, the variation in the size of the maturity between sexes is, generally, explained by a differentiated reproductive needs. The females when directing its energy for reproductive purposes as spawn and incubation of eggs tend to mature with inferior sizes to the males, who invest its resources in somatic growth, reaching larger sizes, favoring cohort and coupling. This fact was registered by LóPEZ-GRECO \& RODRíGUEZ (1999), in reproductive behavior experiments of the same species in nature and laboratory. These authors found that the males were larger females in all the registered cases.

The relations that had better evidenced the sexual maturity was GL vs. CW for males and AW vs. CW for females of C. granulatus (RUFFINo et al., 1994; LóPEZ et al., 1997), and in Goniopsis cruentata (Latreille, 1803) (Cово \& Fransozo, 1998) and in Sesarma rectum Randall, 1840 (Mantelatto \& Fransozo, 1999; Silva \& Chacur, 2002). According to HaRTNOLL (1982), the female abdomen have reproductive attributions, protecting the gonopores and the eggs during the incubation period and the gonopod is related with spermathophore transference. Thus structures can evidence the sexual maturity.

Table II. Maximum size reached by collected specimens of Chasmagnathus granulatus Dana, 1851 in the nature (* approximate values, based on graphs presented by authors).

\begin{tabular}{|c|c|c|c|c|}
\hline Author/year & Locality & Ecosystem & Sex & Largest specimen $(\mathrm{CW})$ \\
\hline RUFFINO et al.,1994 & Lagoa dos Patos RS - Brazil & Salt marsh & $?$ & $25.6 \mathrm{~mm}$ \\
\hline \multirow[t]{2}{*}{ SPIVAK et al., 1994} & Mar Chiquita Lagoon Argentina & Salt marsh & Male & $39.0 \mathrm{~mm} *$ \\
\hline & & & Female & $35.0 \mathrm{~mm} *$ \\
\hline \multirow[t]{2}{*}{ SPIVAK et al., 1996} & Mar Chiquita Lagoon Argentina & Salt marsh & Male & $36.0 \mathrm{~mm}$ \\
\hline & & & Female & $33.0 \mathrm{~mm}$ \\
\hline Stella et al., 1996 & Baía Samborombón Argentina & Salt marsh & Ovigerous & $30.1 \mathrm{~mm}$ \\
\hline \multirow[t]{2}{*}{ LÓPEZ et al., 1997} & Baía Samborombón Argentina & Salt marsh & Male & $29.6 \mathrm{~mm}$ \\
\hline & & & Female & $30.1 \mathrm{~mm}$ \\
\hline \multirow[t]{2}{*}{ López Greco \& RodríGuez, 1999} & Baía Samborombón Argentina & Salt marsh & Male & $31.2 \mathrm{~mm}$ \\
\hline & & & Female & $35.0 \mathrm{~mm}$ \\
\hline \multirow[t]{2}{*}{ LuPPI et al., 2004} & Mar Chiquita Lagoon Argentina & Salt marsh & Male & $34.4 \mathrm{~mm}$ \\
\hline & & & Female & $35.0 \mathrm{~mm}$ \\
\hline \multirow[t]{2}{*}{ Present study } & Rio Jabaquara Paraty RJ - Brazil & Mangrove & Male & $39.5 \mathrm{~mm}$ \\
\hline & & & Female & $36.8 \mathrm{~mm}$ \\
\hline
\end{tabular}


The morphological sexual maturity for $C$. granulatus was evidenced by the relationships $\mathrm{PH} v s$. CW for males and $\mathrm{AW}$ vs. CW for females, corroborating the high allometric index found for the cheliped relations in the above cited papers. In fact, among the Brachyura, the sexual dimorphism is very commonly showed by the cheliped size (Hartnoll, 1974). According to CRANE (1957; 1958), such fact can occur by behavioral reasons, in which the males are more active in territorial disputes, cohort and combats, as presented mainly in the genus Uca Leach, 1814.

Acknowledgements. The authors are indebted with FAPESP (\#94/4878-8 and \#98/3134-6) and CAPES (master science fellowship to the first author) and all help provided by NEBECC members. All the samplings were accomplished according to State and Federal laws concerning wild animals.

\section{REFERENCES}

Botto, F. \& Iribarne, O. 2000. Contrasting effects of two burrowing crabs (Chasmagnathus granulata and Uca uruguayensis) on sediment composition and transport in estuarine environments. Estuarine, coastal and shelf Science 51:141-151.

Campbell, A. \& Eagles, M. D. 1983. Size at maturity and fecundity of rock crabs, Cancer irroratus from the bay of fundy and Southwestern Nova Scotia. Fisheries Bulletin 81(2):357-361.

Coвo, V. J. \& Fransozo, A. 1998. Relative growth of Goniopsis cruentata (Crustacea, Brachyura, Grapsidae), on the Ubatuba region, São Paulo, Brazil. Iheringia, Série Zoologia, 84:21-28.

Colpo, K. D. \& Negreiros-Frasozo, M. L. 2002. Reproductive output of Uca vocator (Herbst, 1804) (Brachyura, Ocypodidae) from three subtropical mangroves in Brazil. Crustaceana 76(1):1-11.

Conde, J. E. \& DíAz, H. 1989. The mangrove crab Aratus pisonii in a tropical estuarine coastal lagoon. Estuarine coast and shelf Science 28:639-650.

CRANe, J. 1957. Basic patterns of displays in fiddler crabs (Ocypodidae, genus Uca). Zoologica 42:69-83.

1958. Aspects of social behavior in fiddler crabs, with special reference to Uca maracoani (Latreille). Zoologica 43:113-130.

Díaz, H. \& Conde, J. E. 1989. Populations dynamics and life history of the mangrove crab Aratus pisonii (Brachyura, Grapsidae) in a marine environment. Bulletin of Marine Science 45(1): 148-163.

Genoni, G. P. 1985. Food limitation in salt marsh fiddler crab $U c a$ rapax (Smith) (Decapoda, Ocypodidae). Journal of Experimental Marine Biology and Ecology 87:97-110.

Giesel, J. T. 1972. Sex ratio, rate of evolution and environment heterogeneity. American Naturalist 106:380-387.

GonZÁlez-Gurriarán, E. \& Freire, J. 1994. Sexual maturity in the velvet swimming crab Necora puber (Brachyura, Portunidae): morphometric and reproductive analyses. Journal of Marine Science 51:133-145.

HAefNer, JR., P. A. \& SpaARgaren, D. H. 1993. Interactions of ovary and hepatopancreas during the reproductive cycle of Crangon crangon (L.). I. weight and volume relationships. Journal of Crustacean Biology 13(3):523-531.

HaRTNOLL, R. G. 1974. Variation in growth pattern between some secundary sexual characters in crabs (Decapoda, Brachyura). Crustaceana 27(2):131-136.

1982. Growth. In: Bliss, D. E. eds. The biology of Crustacea: embriology, morphology and genetics. New York, Academic. p. 11-196.

Hartnoll, R. G. \& Gould, P. 1988. Brachyuran life history strategies and the optimization of egg production. Symposia of the Zoological Society of London 59:1-9.

Huxley, J. S. 1950. Relative growth and form transformation. Proceedings of Royal Society of London 137:465-469.

López, L. S.; Stella, V. S. \& RodríGuez, E. M. 1997. Size at onset of sexual maturity in Chasmagnathus granulata (Decapoda, Brachyura). Nauplius 5(2):65-75.

López-Greco, L. S. \& Rodríguez, E. M. 1999. Annual reproduction and growth of adult crabs Chasmagnathus granulata (Crustacea, Brachyura, Grapsidae). Cahiers de Biologie Marine 40:155-164.

Luppi, T. A.; SpivaK, E. D.; Bas, C. C. \& Anger, K. 2004. Molt and growth of an estuarine crab, Chasmagnathus granulatus (Brachyura, Varunidae), in Mar Chiquita coastal lagoon, Argentina. Journal of Applied Ichthyology 20:333-344.

Mantelatto, F. L. M. \& Fransozo, A. 1999. Relative growth of the crab Sesarma rectum Randall 1840 (Decapoda, Brachyura, Grapsidae) from Bertioga, São Paulo, Brazil. Pakistain Journal of Marine Biology 5(1):11-21.

Montague, C. L. 1980. A natural history of temperature Western Atlantic fiddler crabs (genus $U c a$ ) with reference in their impact on the salt marsh. Contributions of Marine Science 23:25-55.

Ruffino, M. L.; Telles, M. D. \& D’Incao, F. 1994. Reproductive aspects of Chasmagnathus granulata Dana, 1851 (Decapoda, Grapsidae) in the Patos Lagoon Estuary, Brazil. Nauplius 2:43-52.

SHINE, R. 1988. The evolution of large body size in females: a critique of Darwin's "fecundity advantage" model. The American Naturalist 131(1):124-131.

Silva, S. M. \& Chacur, M. M. 2002. Population biology of Sesarma rectum Randall, 1840 (Decapoda, Grapsoidea, Sesarmidae) at Itamambuca mangrove in northern littoral of São Paulo state, Brazil. Nauplius 10(1):47-54

Somerton, D. 1980. A computer technique for estimating the size of sexual maturity in crabs. Canadian Journal of Fishery and Aquatic Science 37:1488-1494.

SpivaK, E. D.; Anger, K.; Luppi, T.; Bas, C. \& Ismael, D. 1994. Distribution and habitat preferences of two grapsid crab species in Mar Chiquita Lagoon (Province of Buenos Aires, Argentina). Helgoländer Meeresunters 48:59-78.

1996. Size structure, sex ratio, and breeding season in two intertidal grapsid crab species from Mar Chiquita lagoon, Argentina. Nerítica 10:7-26

Stella, V. S.; López, L. S. \& Rodríguez, E. M. 1996. Fecundity and brood biomass investment in the estuarine crab Chasmagnathus granulatus Dana, 1851 (Decapoda, Brachyura, Grapsidae). Crustaceana 69(3):306-312.

VANINI, V. \& GuERARDI, F. 1988. Studies on the pebble crab, Eriphia smithi Macley, 1838 (Xanthoidea, Menippidae): patterns of relative growth and populations structure. Tropical Zoologist 1:203-216.

WARNER, G. F. 1967. The life history of the mangrove tree crab Aratus pisonii. Journal of Zoology 153:321-335.

Wolf, P.; Shanholtaer, S. F. \& Reimold, R. J. 1975. Population estimates for Uca pugnax in Duplin estuary marsh, Georgia, USA. Crustaceana 29:79-91.

ZAR, J. H. 1996. Biostatistical analysis. Prentice-Hall, Upper Saddle River. 662p 